\title{
Sentiment Analysis Berbasis Algoritma Naïve Bayes Classsifier untuk Identifikasi Persepsi Masyarakat Terhadap Produk / Layanan Perusahaan
}

\author{
Affandy $^{1}$, Oktania Nandiyati ${ }^{2}$ \\ Fakultas Ilmu Komputer, Universitas Dian Nuswantoro Semarang \\ Jl.Imam Bonjol No.207 Semarang, telp. (024) 3569196 \\ e-mail: ${ }^{1}$ affandy@dsn.dinus.ac.id, ${ }^{2}$ oktaniandyt@gmail.com \\ Diterima: 11 Mei 2019; Direvisi: 30 Mei 2020; Disetujui: 31 Mei 2020
}

\begin{abstract}
Abstrak
Twitter merupakan layanan microblogging terpopuler di Indonesia, dengan jumlah pengguna mencapai hampir 23 juta. Di era big data seperti saat ini tweets atau "kicauan" dari pelanggan, pemerhati, konsumen potensial, atau masyarakat dari pengguna produk atau layanan dari suatu perusahaan akan sangat membantu perusahaan dalam mengetahui lanskap industri dan konsumen, sehingga dapat menentukan langkah strategis yang akan menyumbangkan kontribusi terhadap pertumbuhan perusahaan. Namun demikian pemanfaatan data dari media sosial Twitter terkendala dengan sejumlah kesulitan teknis dalam proses pengumpulannya, pengolahannya, serta analisanya. Secara spesifik penelitian ini menerapkan algoritma Naüve Bayes Classifier dalam proses analisa sentimen pada data tweets ke dalam sebuah prototipe aplikasi yang ditujukan untuk memudahkan perusahaan/organisasi mengetahui persepsi masyarakat terhadap produk atau layanan yang dimiliki. Algoritma NBC dipilih karena algoritma ini mampu melakukan klasifikasi dengan baik walaupun menggunakan data training yang kecil, namun memiliki akurasi dan kecepatan proses yang tinggi untuk penanganan data training yang besar. Dari hasil evaluasi didapati prototipe berjalan dengan baik dimana keyword yang dimasukkan akan mentriger Twitter API untuk melakukan crawling selanjutnya proses mining dapat terpantau di tiap tahapan dan di akhir proses, sistem akan menunjukkan nilai akhir level sentiment serta representasi log hasil perhitungan dalam bentuk chart dengan kurun waktu tertentu.
\end{abstract}

Kata kunci: twitter, sentiment analysis, klasifikasi, naïve bayes classifier, prototype

\begin{abstract}
Twitter is the most popular microblogging service in Indonesia, with nearly 23 million users. In the era of big data such as the current tweets from customers, observers, potential consumers, or the community of users of products or services of a company will greatly help companies in knowing the industrial and consumer landscape, so as to determine strategic plans that will contribute to the company's growth. However, the use of data from social media such as Twitter is hampered by a number of technical difficulties in the process of collecting, processing, and analysing. Specifically, this research applies the Nä̈ve Bayes Classifier algorithm in the process of sentiment analysis of tweets data into a prototype application that is intended to make it easier for companies / organizations to know people's perceptions of their products or services. The $N B C$ algorithm was chosen because this algorithm is able to do a good classification even though it uses small training data, but has high accuracy and process speed for handling large training data. From the evaluation results found a prototype running well where the keywords entered will
\end{abstract}


trigger the Twitter API to crawl the data then the mining process can be monitored at each stage and at the end of the process, the system will show the final sentiment level values and the representation of the calculation results log in a chart form over a certain period of time.

Keywords: twitter, sentiment analysis, classification, naïve bayes classifier, prototype

\section{PENDAHULUAN}

Riset dari Hootsuite, lembaga manajemen media sosial, dan We Are Social, perusahaan agensi global, di awal tahun 2020 menyebutkan bahwa hingga saat ini potensi pengguna media sosial di Indonesia mencapai 160 juta pengguna (kisaran lebih dari 59\% dari total penduduk Indonesia) [1]. Angka ini meningkat cukup signifikan, mencapai $17 \%$, dari jumlah pengguna di tahun sebelumnya. Sementara itu hasil analisa dan statistik web trafic di Indonesia diketahui 4 dari 10 website yang paling sering diakses hingga Februari 2020 adalah situs media sosial yang diantaranya adalah: Youtube, Facebook, Instagram, dan Twitter [2]. Hal ini menunjukkan bahwa kepemilikian akun dalam media sosial menjadi suatu kebutuhan bagi siapapun yang beraktifitas dengan memanfaatkan teknologi internet. Media sosial sering kali dimaknai sebagai platform teknologi interaktif dengan media komputer dan internet yang memfasilitasi penciptaan dan pendistribusian informasi, ide, hobi atau minat, dan berbagai bentuk ekspresi lainnya melalui jaringan dan komunitas virtual [3].

Salah satu model media sosial yang berkembang saat ini adalah platform microblogging, media broadcast online yang memungkinkan penggunanya untuk bertukar elemen dari konten yang berukuran kecil atau pendek yang dapat berbentuk kalimat ringkas, gambar tunggal, ataupun link dari suatu video. Pesan dengan ukuran kecil ini sering juga disebut dengan micropost. Karena ukurannya yang relatif kecil inilah yang menjadikan situs penyedia microblogging ini menjadi populer (Twitter, Mastodon, Amino, dan sebagainya). Twitter merupakan layanan microblogging terpopuler di Indonesia, dengan jumlah mencapai hampir 23 juta pengguna, dengan peningkatan mencapai dua kali lipatnya dari lima tahun sebelumnya [4]. Menurut data yang telah dirilis oleh Twitter pada akhir tahun 2016 lalu, dikatakan bahwa jumlah tweets yang dihasilkan oleh pengguna Twitter Indonesia sepanjang tahun 2016 mencapai 4.1 miliar tweets [5].

Jumlah tweets yang terekam dalam bentuk teks digital dengan volume yang sangat besar ini tentunya menyimpan pengetahuan yang sangat berharga, utamanya bagi dunia bisnis. Di era big data seperti saat ini tweets atau "kicauan" dari pelanggan, pemerhati, konsumen potensial, atau masyarakat dari pengguna produk atau layanan dari suatu perusahaan akan sangat membantu perusahaan dalam mengetahui lanskap industri dan konsumen, sehingga dapat menentukan langkah strategis yang akan menyumbangkan kontribusi terhadap pertumbuhan perusahaan. Penilaian dari publik terkait dengan kualitas produk atau layanan, fitur yang ditawarkan, tingkat kepuasan, dan berbagai hal lainnya akan sangat membatu perusahaan dalam menentukan karakteristik konsumen, ekspektasi konsumen, dan persepsi konsumen terhadap citra perusahaan. Namun demikian pemanfaatan data dari media sosial khususnya Twitter terkendala dengan sejumlah kesulitan teknis dalam proses pengumpulannya, pengolahannya, serta analisanya [6].

Di dalam bidang ilmu komputasi, analisa sentimen dari opini masyarakat yang dituangkan dalam bentuk teks termasuk dalam bidang kajian text mining dengan sub-kajian opinion mining. Fungsi utama dari analisis sentimen adalah menghasilkan kelompok polaritas dari teks yang ada pada sekumpulan dokumen yang selanjutnya diidentifikasi apakah dokumen mengandung pendapat yang bersifat positif, negatif, ataupun netral [6]. Sejumlah algoritma telah banyak diterapkan dalam kasus analisa sentimen yang diantaranya Naïve Bayes Classifier (NBC), Support Vector Machine (SVM), K-Nearest Neighbor (K-NN), Decision Tree, dan sebagainya. $[7,8,9,10]$. K-NN merupakan algoritma yang paling umum digunakan namun demikian K-NN memiliki kelemahan apabila menangani data training dalam jumlah yang kecil. Sebaliknya dengan SVM yang memiliki performa baik pada data training yang kecil namun demikian konsistensi performa SVM menurun seiring dengan peningkatan jumlah data [11, 12]. Solusi 
terbaik diantara dua algoritma tersebut dimiliki oleh NBC, dimana algoritma ini mampu melakukan klasifikasi dengan baik walaupun menggunakan data training yang kecil, namun memiliki akurasi dan kecepatan proses yang tinggi untuk penanganan data training yang besar [12].

Secara spesifik penelitian ini menerapkan algoritma NBC dalam proses analisa sentimen pada data tweets ke dalam sebuah prototipe aplikasi yang ditujukan untuk memudahkan perusahaan / organisasi mengetahui persepsi masyarakat terhadap produk atau layanan yang dimiliki. Paparan latar belakang masalah telah disampaikan pada paragraf-paragraf di atas yang selanjutnya diikuti dengan bahasan metode penelitian dan pembahasan. Kesimpulan dan usulan riset lanjutan dipaparkan pada bagian akhir laporan penelitian ini.

\section{METODE PENELITAN}

Sebagai bentuk dari penelitian di bidang data mining, tahapan pelaksanaan penelitian ini mengacu pada kerangka kerja Cross-Industry Processing for Data Mining (CRISP-DM). Kerangka kerja ini menyediakan pendekatan yang terstruktur untuk perencanaan proyek / penelitian data mining [13].

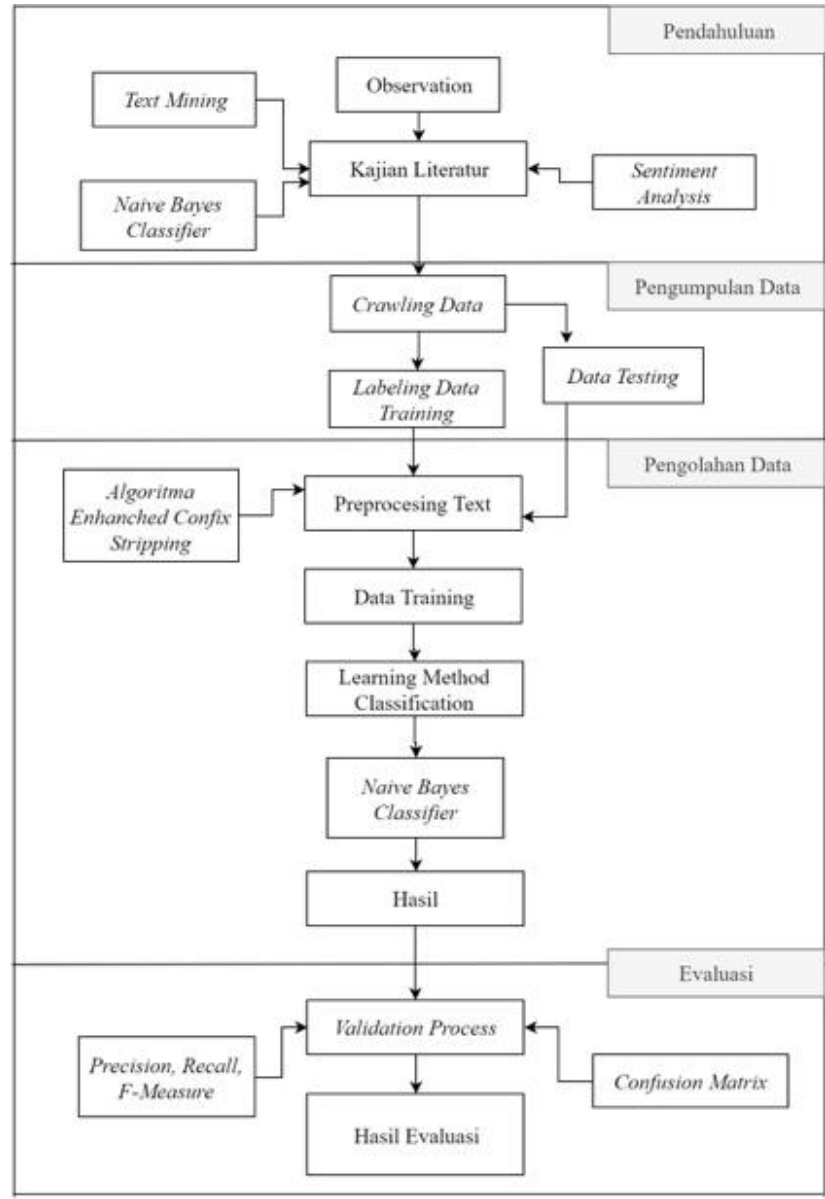

Gambar 1. Metode penelitian

Dari gambar 1 diatas dapat dijelaskan dalam beberapa tahapan diantaranya:

1. Penentuan tujuan bisnis, dari perspektif bisnis penelitian ini bertujuan untuk mengetahui persepsi pengguna media sosial Twitter terhadap produk/layanan dari suatu perusahaan. Untuk memudahkan proses identifikasi dikembangkan sebuah prototipe aplikasi bantu untuk 
mengumpulkan tweets, melakukan pre-processing dari tweets yang terkumpul, melakukan proses klasifikasi opini dari tweets, dan merepesentasikan statistik dari hasil klasifikasi.

2. Pemahaman data, proses pengumpulan data dilakukan dengan teknik crawling dimana semua tweets yang relevan dengan keyword yang ditentukan akan ditarik untuk dijadikan sebagai dataset. Proses crawling menggunakan library TwitterOAuth() dan fungsi get('search/tweets') yang disediakan dari Twitter API. Dari dataset yang didapatkan selanjutnya akan dibagi menjadi data training dan data testing.

3. Persiapan data, tweets yang terkumpul umumnya dalam bentuk tidak terstruktur atau semi terstruktur. Proses konversi terhadap data perlu dilakukan sebelum proses klasifikasi dijalankan, adapun proses tersebut meliputi: (a) merubah semua teks menjadi lower case dan menghapus semua karakter yang bukan huruf (case folding), (b) merubah struktur kalimat menjadi kata atau term (tokenizing), (c) merubah setiap kata menjadi kata dasar (stemming), proses stemming dilakukan dengan menggunakan algoritma Enhanced Confix-Stripping (ECS), dan (d) menghapus semua kata hubung, kata depan, kata ganti, dan keyword pencarian data saat proses pengumpulan data dilakukan (stopword removal). Daftar kata stopword yang digunakan pada penelitian ini bersumber dari Tala [14].

4. Penentuan model mining, fungsi mining yang akan dijalankan dalam penelitian adalah fungsi klasifikasi, dimana data yang terkumpul akan dikelompokkan ke dalam 3 label sentimen yang meliputi positif, negatif, dan normal. Dari proses kajian literatur penelitian disimpulkan bahwa proses klasifikasi akan menggunakan algoritma Naïve Bayes Classifier (NBC). Secara umum teori Bayes merupakan teori perbandingan peluang dari hipotesa dengan rumus umum sebagai berikut:

$$
\mathrm{P}(\mathrm{C} \mid \mathrm{O})=\frac{\mathrm{P}(\mathrm{O} \mid \mathrm{C}) \times \mathrm{P}(\mathrm{C})}{\mathrm{P}(\mathrm{O})}
$$

Dimana:

$$
\begin{array}{ll}
\mathrm{P}(\mathrm{C} \mid \mathrm{O}) & =\text { Probabilitas hipotesis berdasarkan kondisi } \\
\mathrm{P}(\mathrm{O} \mid \mathrm{C}) & =\text { Probabilitas berdasarkan kondisi pada hipotesis } \\
\mathrm{C} & =\text { Hipotesis data merupakan kelas spesifik } \\
\mathrm{O} & =\text { Data dengan kelas yang belum diketahui } \\
\mathrm{P}(\mathrm{O}) & =\text { Probabilitas } \mathrm{O}
\end{array}
$$

Pada proses klasifikasi sentimen formula NBC adalah sebagai berikut

$$
\mathrm{V}_{M A P}=\underset{V j e V}{\operatorname{argmax}} \mathrm{P}(\mathrm{Vj}) \prod \mathrm{P}\left(x_{1} \mid \mathrm{Vj}\right)
$$

Dimana $\mathrm{V}_{\mathrm{MAP}}$ merupakan probabilitas tertinggi dari semua kelas yang diujikan. Sedangkan $\mathrm{P}(\mathrm{Vj})$ dan $\mathrm{P}(\mathrm{x} 1 \mid \mathrm{Vj})$ dilakukan pada saat training menggunakan persamaan 3 dan 4 sebagai berikut:

$$
\begin{aligned}
& \mathrm{P}(\mathrm{Vj})=\frac{\mid \text { docs } \mathrm{j} \mid}{\mid \text { docstraining } \mid} \\
& \mathrm{P}\left(x_{1} \mid \mathrm{Vj}\right)=\frac{\mathrm{ni}+1}{\mathrm{n}+\mid \text { kosakata } \mid}
\end{aligned}
$$

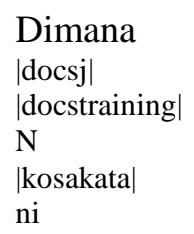

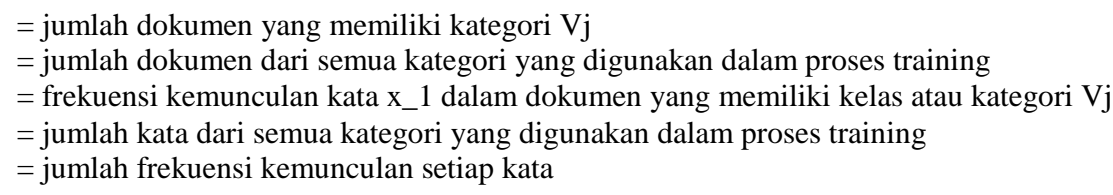


5. Proses evaluasi model, hasil klasifikasi selanjutnya akan diuji menggunakan pendekatan confusion matrix, dimana rasio data aktual akan dibandingkan dengan data hasil klasifikasi dari model. Instrumen evaluasi klasifikasi diukur dengan menggunakan ukuran accuracy, precision, recall dan $f$-measure.

6. Deployment, pada tahapan ini data keyword yang diinputkan, proses klasifikasi, evaluasi, dan representasi pengetahuan yang didapat di-deploy melalui sebuah prototipe aplikasi yang dirancang dengan tujuan memudahkan perusahaan atau organisasi dalam proses identifikasi persepsi publik terhadap suatu produk/layanan yang diinputkan sebagai keyword.

\section{HASIL DAN PEMBAHASAN}

Paparan berikut ini menjelaskan proses pengembangan prototipe aplikasi dengan mengimplementasikan algoritma NBC untuk mendapatkan representasi sentimen atau persepsi masyarakat yang didapat dari teks pada Twitter dari masukan berupa keyword yang menggambarkan produk atau layanan, atau nama brand atau nama organisasi. Tahapan pengembangan hingga evaluasi aplikasi dipaparkan mengikuti software proses model prototyping.

\subsection{Analisa Kebutuhan Sistem}

Secara garis besar kebutuhan sistem dikelompokkan ke dalam dua kategori, yakni kebutuhan functional dan non-functional. Paparan rinci kebutuhan tersebut dapat dilihat pada tabel 1 di bawah ini:

Tabel 1. Daftar kebutuhan fungsional dan non-fungsional dari sistem

\begin{tabular}{ll}
\hline ID & Deskripsi Kebutuhan Fungsional \\
\hline R1 & $\begin{array}{l}\text { User dapat memasukkan keyword sesuai kebutuhan yang kemudian oleh system digunakan untuk } \\
\text { mengumpulkan semua tweets yang relevan dengan keyword tersebut. }\end{array}$ \\
R2 & $\begin{array}{l}\text { User dapat membatasi jumlah tweets yang dikumpulkan sesuai kebutuhan. } \\
\text { User dapat mereview hasil klasifikasi tiap-tiap tweets dengan memperhatikan nilai probabilitas } \\
\text { positif, negatif, dan netral serta hasil akhir klasifikasi sentimen. }\end{array}$ \\
R4 & $\begin{array}{l}\text { User dapat menyimpan hasil analisa dalam bentuk log sehingga dapat digunakan untuk } \\
\text { monitoring perkembangan sentimen dari waktu ke waktu. }\end{array}$ \\
R5 & $\begin{array}{l}\text { User dapat melihat representasi hasil akhir dari klasifikasi sentimen dan perkembangan sentimen } \\
\text { dalam bentuk chart sederhana. }\end{array}$ \\
\hline ID & Deskripsi Kebutuhan Non-Fungsional \\
\hline R6 & $\begin{array}{l}\text { Rancangan } \text { user interface mudah dipahami dengan proses interaksi yang simpel. } \\
\text { R7 }\end{array}$ \\
Output dalam bentuk chart yang jelas dan kontras untuk membedakan masing-masing kelas \\
R8
\end{tabular}

\subsection{Modelling Quick Design}

Pada tahapan ini dikembangkan model desain yang fokus pada representasi aspek-aspek software yang tampak oleh user yang meliputi interface layout, bentuk keluaran, dan kontrol interaksi. Berikut ini adalah beberapa desain utama pada prototipe aplikasi analisa sentimen dari media sosial Twitter ditunjukkan pada gambar 2. 

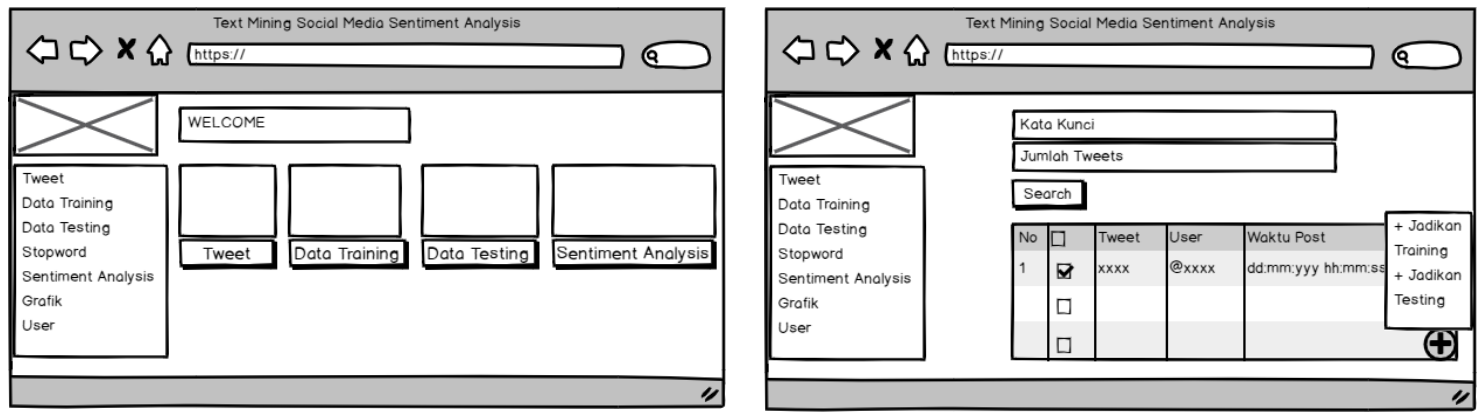

Gambar 2. Rancangan interface untu prototipe aplikasi sentimen analisis

\subsection{Pengembangan Prototipe}

Pada tahapan ini spesifikasi sistem yang telah ditentukan diubah menjadi unit kerja yang lebih teknis. Sejumlah tool pengembang seperti html, php, css, dan javascript digunakan untuk konstruksi user interface, kontrol, dan implementasi algoritma NBC. Untuk pengelolaan basis data sistem memanfaatkan mysql, sedangkan framework yang digunakan dalam pembuatan sistem adalah framework laravel. Secara umum struktur program terbangun dalam 5 bagian yang meliputi: pengumpulan data tweets (crawling), pendefinisian dataset (testing dan training), preprocessing dan transformasi text, proses klasifikasi, visualisasi dan evaluasi, sebagaimana tampak pada gambar 3.

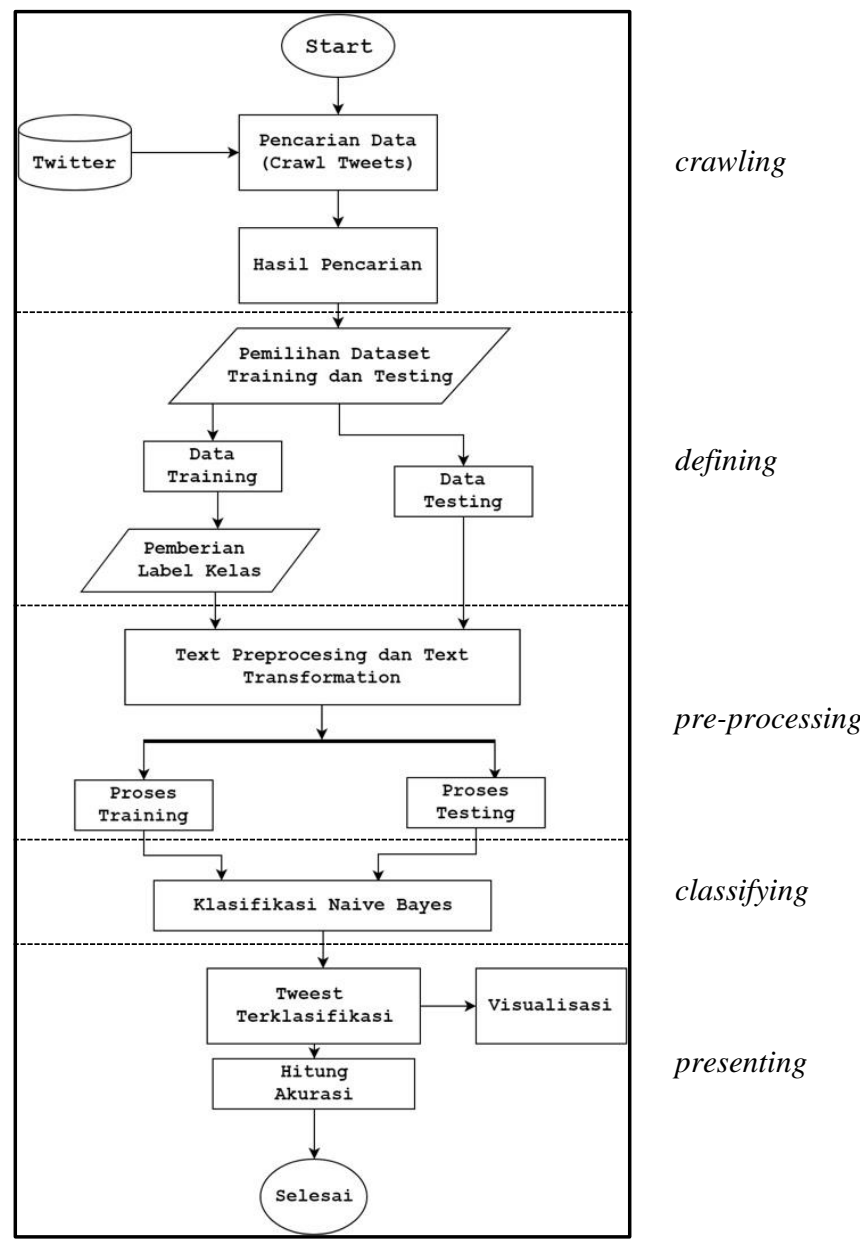

Gambar 3. Struktur prototipe program aplikasi analisa sentimen 
Berikut ini adalah hasil keluaran dari pengembangan prototipe pada modul crawling dan transformasi teks Twitter pada gambar 4. Keluaran ini merupakan hasil olahan dari bagian preprocessing sebagaimana tampak pada struktur program pada gambar 4

\begin{tabular}{|c|c|c|}
\hline Username & Tweet & Tanggal \\
\hline Anggijendriadi & $\begin{array}{l}\text { Min a } 2 \text { minggu belakangan ini } \\
\text { lemot banget di gedung menara karya, } \\
\text { mohon diperbaiki dong min. Terima } \\
\text { kasih. }\end{array}$ & $\begin{array}{l}2019- \\
10-04\end{array}$ \\
\hline Cepots & $\begin{array}{l}\text { Ini tiap bulan bayar mahal kok internet } \\
\text { gue lemot bgt, sinyalnya hilang- } \\
\text { hilangan @@ }\end{array}$ & $\begin{array}{l}2019- \\
10-04\end{array}$ \\
\hline Pikhacuwu & $\begin{array}{l}\text { Kalo mau upgrade kartu telkomsel yg } \\
3 \mathrm{G} \text { ke } 4 \mathrm{G} \text { bayar berapa ya gengs? }\end{array}$ & $\begin{array}{l}2019- \\
10-04\end{array}$ \\
\hline pusstyle07 & $\begin{array}{l}\text { Guys yg pake } \\
\text { rekomendasiin paketan internet yang } \\
\text { murah meriah dan banyak } \\
\text { menguntungkan ga?? }\end{array}$ & $\begin{array}{l}2019- \\
10-04\end{array}$ \\
\hline Nurulhanifaaaaa & \begin{tabular}{l|l} 
Terima kasih & hehehe promo \\
disaat yg sangat tepat &
\end{tabular} & $\begin{array}{l}2019- \\
10-04\end{array}$ \\
\hline f_rahmadani 67 & \begin{tabular}{l|l} 
Asik & promonya mantab $50 \mathrm{gb}$ \\
&
\end{tabular} & $\begin{array}{l}2019- \\
10-04\end{array}$ \\
\hline
\end{tabular}

\begin{tabular}{|l|l|}
\hline \multicolumn{1}{|c|}{ Tweets } & \multicolumn{1}{|c|}{ Transformation } \\
\hline $\begin{array}{l}\text { Min @anapa jaringan } \\
\text { minggu belakangan ini lemot banget di gedung } \\
\text { menara karya, mohon diperbaiki dong min. } \\
\text { Terima kasih. }\end{array}$ & $\begin{array}{l}\text { [jaring] [minggu] [belakang] } \\
{[\text { lemot] [gedung] [menara] }} \\
{[\text { karya] [mohon] [baik] [terima] }} \\
\text { [kasih] }\end{array}$ \\
\hline $\begin{array}{l}\text { Ini tiap bulan bayar mahal kok internet gue lemot } \\
\text { bgt, sinyalnya hilang-hilangan @ }\end{array}$ & $\begin{array}{l}\text { [bayar] [mahal] [internet] } \\
\text { [lemot] [sinyal] [hilang] }\end{array}$ \\
\hline $\begin{array}{l}\text { Kalo mau upgrade kartu telkomsel yg 3G ke 4G } \\
\text { bayar berapa ya gengs? }\end{array}$ & [kalo] [kartu] [bayar] [berapa] \\
\hline $\begin{array}{l}\text { Guys yg pake ada yg bisa } \\
\text { rekomendasiin paketan internet yang murah } \\
\text { meriah dan banyak menguntungkan ga?? }\end{array}$ & $\begin{array}{l}\text { [rekomendasi] [paket] [internet] } \\
\text { [murah] [riah] [untung] }\end{array}$ \\
\hline $\begin{array}{l}\text { Terima kasih t } \\
\text { sangat tepat hehehe promo disaat yg }\end{array}$ & [terima] [kasih] [promo] [saat] \\
[tepat]
\end{tabular}

Gambar 4. Keluaran dari proses pre-processing dan text transformation

\subsection{Deployment dan Feedback}

Di akhir proses pengembangan sistem selanjutnya memasuki tahapan pengujian, dimana proses verifikasi dan validasi dilakukan dengan mengacu pada daftar spesifikasi kebutuhan yang telah ditentukan dan logika program melalui skenario testing program yang telah dibuat.

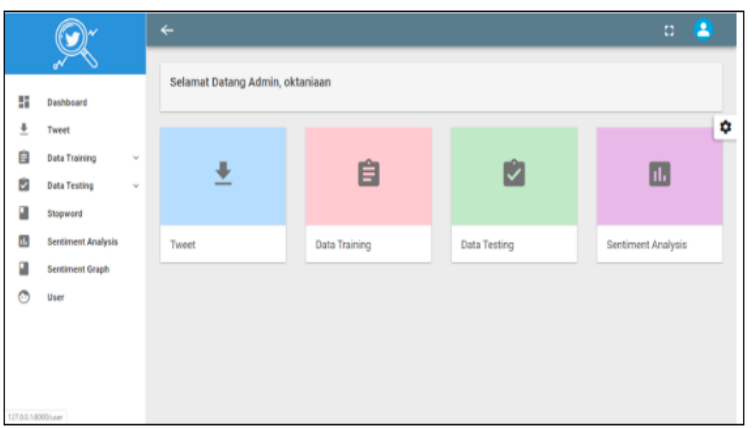

(a)

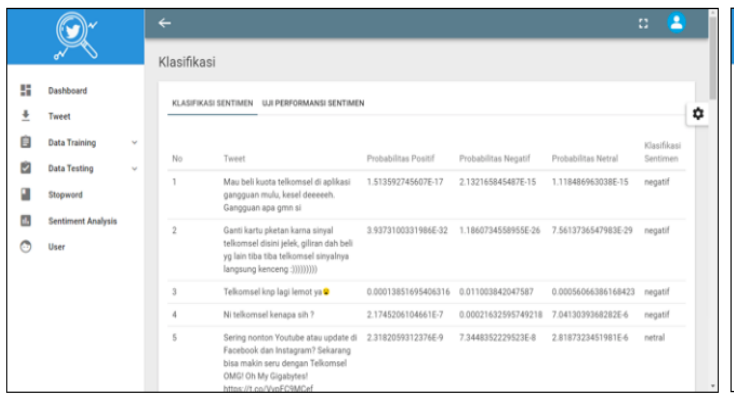

(c)

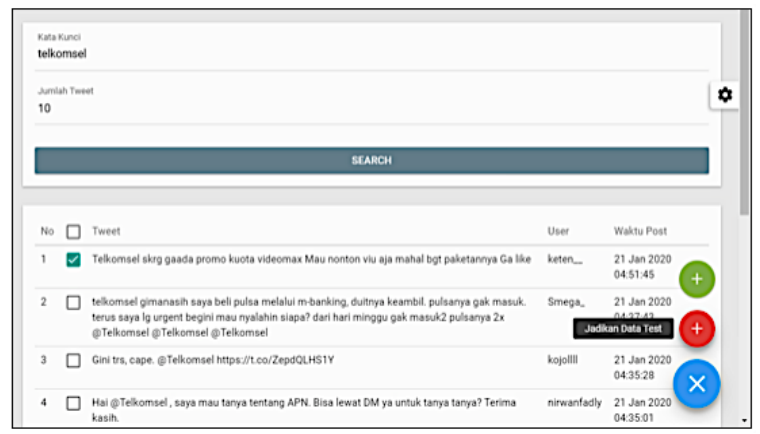

(b)

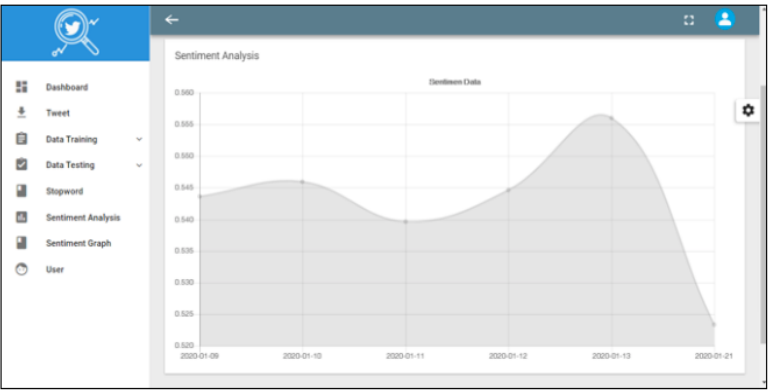

(d)

Gambar 5. Kondisi prototipe saat dijalankan

(a) tampilan awal, (b) hasil crawling, (c) proses klasifikasi, (d) representasi hasil klasifikasi

Dari hasil evaluasi didapati prototipe yang tampak pada gambar 5 berjalan dengan baik dimana keyword yang dimasukkan akan mentriger Twitter API untuk melakukan crawling selama tujuh hari sebelumnya pada gambar 5.b. Sementara itu masukkan untuk jumlah tweets yang 
dikelola akan mengontrol jumlah tweets yang akan ditampilkan pada tabel view. Tahapan proses mining dapat terpantau pada bagian/sheet Text-PreProcessing, Text Transformation, Unigram, dan Unigram Frequency. Demikian juga dengan proses klasifikasi, sistem secara detail dapat menampilkan hasil klasifikasi dari suatu teks tweets berikut dengan nilai probabilitasnya yang dikalkulasi mengikuti rumus persamaan 3 dan 4 dan tampak pada gambar 5.c.

Sebagai contoh apabila dari hasil preprocessing didapatkan term [parah] [paket] [mahal] [sinyal] [hilang] maka $\mathrm{P}(\mathrm{Vj})$ pada setiap kategori dapat dihitung dengan menggunakan rumus persamaan 3.

1. Probabilitas $\mathrm{P}\left(C_{\text {positif }}\right) \quad \rightarrow \quad \mathrm{P}\left(C_{\text {positif }}\right)=\frac{|2|}{|6|}=0.333$

2. Probabilitas $\mathrm{P}\left(C_{\text {negatif }}\right) \rightarrow \mathrm{P}\left(C_{\text {negatif }}\right)=\frac{|2|}{|6|}=0.333$

3. Probabilitas $\mathrm{P}\left(C_{\text {netral }}\right) \quad \rightarrow \quad \mathrm{P}\left(C_{\text {netral }}\right)=\frac{|2|}{|6|}=0.333$

Untuk selanjutnya proses identifikasi dalam penentuan kelas mana yang paling tepat untuk potongan tweets tersebut perhitungan dilakukan dengan mengacu pada rumus persamaan 4 .

1. Probabilitas data testing terhadap kelas Positif

$\mathrm{P}$ (parah|Positif): $(0+1) /(8+29)=0.0270$

$\mathrm{P}$ (paket|Positif): $(0+1) /(8+29)=0.0270$

$\mathrm{P}$ (mahal|Positif): $(0+1) /(8+29)=0.0270$

2. Probabilitas data testing terhadap kelas Negatif

$\mathrm{P}($ parah/Negatif $):(0+1) /(17+29)=0.0217$

$\mathrm{P}$ (paket|Negatif): $(0+1) /(17+29)=0.0217$

$\mathrm{P}($ mahal $\mid$ Negatif $):(1+1) /(17+29)=0.0435$

3. Probabilitas data testing terhadap kelas Netral

$\mathrm{P}($ parah|Netral $):(0+1) /(10+29)=0.0256$

$\mathrm{P}($ paket|Netral $):(1+1) /(10+29)=0.0513$

$\mathrm{P}($ mahal|Netral $):(0+1) /(10+29)=0.0256$

$\mathrm{P}($ sinyal|Positif): $(0+1) /(8+29)=0.0270$

$\mathrm{P}$ (hilang|Positif): $(0+1) /(8+29)=0.0270$

$\mathrm{P}($ sinyal|Negatif $):(1+1) /(17+29)=0.0435$

$\mathrm{P}($ hilang|Negatif $):(1+1) /(17+29)=0.0435$

$\mathrm{P}($ sinyal|Netral $):(0+1) /(10+29)=0.0256$

$\mathrm{P}$ (hilang $\mid$ Netral $):(0+1) /(10+29)=0.0256$

Setelah pada data testing probabilitas pada setiap term terhadap setiap kelas telah diketahui. Maka dapat dilanjutkan dengan menghitung probabilitas dari $\mathrm{P}\left(x_{i} \mid V j\right) \mathrm{P}(\mathrm{Vj})$ untuk menentukan kelas yang tepat pada data testing.

1. Kelas Positif atau $\mathrm{P}($ Positif|testing)

$=\mathrm{P}\left(C_{\text {positif }}\right) \times \mathrm{P}($ parah $\mid$ Positif $) \times \mathrm{P}($ paket $\mid$ Positif $) \times \mathrm{P}($ mahal|Positif $) \times \mathrm{P}($ sinyal|Positif) $\times \mathrm{P}($ hilang|Positif $)$

$=0.333 \times 0.0270 \times 0.0270 \times 0.0270 \times 0.0270 \times 0.0270$

$=4.78 \times 10^{-9}$

2. Kelas Negatif atau $\mathrm{P}($ Negatif $\mid$ testing $)$

$=\mathrm{P}\left(C_{\text {negatif }}\right) \times \mathrm{P}($ parah $\mid$ Negatif $) \times \mathrm{P}($ paket|Negatif $) \times \mathrm{P}($ mahal|Negtif $) \times \mathrm{P}($ sinyal| $\mid$ egtif $) \times \mathrm{P}($ hilang $\mid$ Negatif $)$

$=0.333 \times 0.0217 \times 0.0217 \times 0.0435 \times 0.0435 \times 0.0435$

$=1.29 \times 10^{-8}$

3. Kelas Netral atau $\mathrm{P}($ Netral|testing)

$=\mathrm{P}\left(C_{\text {netral }}\right) \times \mathrm{P}($ parah $\mid$ Netral $) \times \mathrm{P}($ paket $\mid$ Netral $) \times \mathrm{P}($ mahal $\mid$ Netral $) \times \mathrm{P}($ sinyal $\mid$ Netral $) \times \mathrm{P}($ hilang $\mid$ Netral $)$

$=0.333 \times 0.0256 \times 0.0513 \times 0.0256 \times 0.0256 \times 0.0256$

$=7.34 \times 10^{-9}$

Dari proses perhitungan tampak bahwa probabilitas tertinggi ada pada kelas Negatif (1.29 x $10^{-8}$ ) maka tweets "parah paket mahal sinyal hilang" diklasifikasikan sebagai sentimen negatif.

Di akhir proses, sistem akan menunjukkan nilai akhir dari proses sentimen analysis berdasarkan data yang telah di-crawling. Apabila dikehendaki user dapat menyimpan log hasil perhitungan dan menampilkannya dalam bentuk chart dengan kurun waktu tertentu tampak pada gambar 5.d. 


\section{KESIMPULAN DAN RISET LANJUTAN}

Berdasarkan hasil uraian pada pembahasan dan sejumlah temuan dalam proses pengembangan penelitian ini, didapati bahwa prototipe aplikasi dapat bekerja dengan baik sesuai dengan kebutuhan sistem. Perusahaan atau organisasi dapat dengan mudah mengidentifikasi persepi masyarakat terkait dengan produk/layanan yang sedang diamati. Proses crawling, preprocessing dan representasi hasil dapat dengan mudah dimanfaatkan walau hanya dengan literasi komputasi yang minim. Dari sejumlah percobaan didapati penerapan algoritma NBC pada analisa sentimen dari data tweets ini memiliki rerata akurasi presisi sebesar 88\%, dengan pencapaian recall $90 \%$ serta F1 score sebesar $89 \%$. Proses crawling sendiri secara umum bergantung pada kualitas koneksi internet, dari sejumlah percobaan proses crawling yang menghasilkan rerata 100 tweets membutuhkan rerata waktu kurang dari 5 menit, demikian juga untuk proses klasifikasinya.

Sejumlah kelemahan terkait dengan riset ini yang membuka kesempatan untuk dapat dilakukannya perbaikan sebagai kelanjutan riset diantaranya adalah perlunya mendapatkan tool atau strategi yang memungkinkan durasi periode crawling melebihi 7 hari, penyusunan algoritma pencarian yang dapat mengkombinasikan keyword pencarian dengan sejumlah notasi logika agar query pencarian lebih fleksibel dengan ruang lingkup hasil yang lebih tajam. Representasi hasil analisa sentimen dalam bentuk chart hanya memaparkan rasio sentimen positif dan netral terhadap keseluruhan tweets yang didapat, detail jumlah untuk masing-masing sentimen belum tergambarkan dengan jelas sehingga perlu ada perbaikan dalam penyediaan informasi tersebut.

\section{DAFTAR PUSTAKA}

[1] K., Simon, "Digital 2020: Indonesia" 2020. [Online]. Available: https://datareportal.com/reports/digital-2020-indonesia [Accessed 0303 2020].

[2] Similarweb LTD, "Top sites ranking for all categories in Indonesia" 2020. [Online]. Available: https://www.similarweb.com/top-websites/indonesia [Accessed 0403 2020].

[3] Obar, Jonathan A.; Wildman, Steve (2015). "Social media definition and the governance challenge: An introduction to the special issue". Telecommunications Policy. 39 (9): 745750. doi:10.1016/j.telpol.2015.07.014. SSRN 2647377.

[4] Statista, "Number of Twitter users in Indonesia from 2014 to 2019" 2020. [Online]. Available: https://www.statista.com/statistics/490548/twitter-users-indonesia/ [Accessed 04 03 2020]

[5] Carley, Kathleen \& Malik, Momin \& Kowalchuck, Michael \& Pfeffer, Juergen \& Landwehr, Peter. (2015). Twitter Usage in Indonesia. 10.13140/RG.2.1.2163.9925.

[6] A., Alamsyah, "(Big) Data Analytics for Economics, Business and Management: A Social Network Approach,” dalam In Workshop Big Data Puslitbang Aptika dan IKP, 2015.

[7] J. Ipmawati, Kusrini dan E. T. Luthfi, "Komparasi Teknik Klasifikasi Teks Mining Pada Analisis Sentimen," Indonesian Journal on Networking and Security, vol. VI, no. 1, pp. 2836, 2017.

[8] R. Sari, "Komparasi Algoritma Support Vector Machine, Naïve Bayes Dan C4.5 Untuk Klasifikasi SMS," Indonesian Journal on Computer and Information Technology, vol. II, no. 2, pp. 7-13, 2017 .

[9] Hermanto, S. J. Kuryanti dan S. N. Khasanah, "Comparison of Naïve Bayes Algorithm, C4.5 and Random Forest for Service Classification Ojek Online," Journal Publications \& Informatics Engineering Research, vol. III, no. 2, pp. 266-274, 2019. 
[10] Y. Aggraini, Sucipto dan R. Indriati, "Cyberbullying Detection Modelling at Twitter Social Networking," Information System, vol. VI, no. 2, pp. 113-118, 2018.

[11] S. K. Lidya, O. S. Sitompul dan S. Efendi, "Sentimen Analisis pada Teks Bahasa Indonesia Menggunakan Support Vector Machine dan K-Nearest Neighbor," dalam Seminar Nasional Teknologi Informasi dan Komunikasi (SENTIKA), Yogyakarta , 2015.

[12] R. N. Devita, H. W. Herwanto dan A. P. Wibawa , "Perbandingan Kinerja Metode Naive Bayes dan K-Nearest Neighbor untuk Klasifikasi Artikel Bahasa Indonesia," Jurnal Teknologi Informasi dan Ilmu Komputer, vol. 5, no. 4, pp. 427-434, 2018 .

[13] Wirth, R., \& Hipp, J. (2000, April). CRISP-DM: Towards a standard process model for data mining. In Proceedings of the 4th international conference on the practical applications of knowledge discovery and data mining (pp. 29-39). London, UK: Springer-Verlag.

[14] F. Z. Tala, "A Study of Stemming Effects on Information Retrieval in Bahasa Indonesia," Institute for Logic, Language and Computation Universiteit Van Amsterdam The Netherlands, 2003. 